\title{
Modification of CSE-UCLA and Discrepancy as a New Evaluation Model in Education
}

\author{
P. Wayan Arta Suyasa ${ }^{1}$, Dewa Gede Hendra Divayana ${ }^{1 *}$ \\ ${ }^{I}$ Department of IT Education,Universitas Pendidikan Ganesha, Jl. Udayana No. 11 Singaraja, Bali, 81116, Indonesia
}

\begin{abstract}
The absence of an evaluation model that can be used to evaluate the effectiveness of educational activities at vocational universities in the view of six domains causes the need to find innovations in an evaluation model. The six domains, included: context, input, socialization process, implementation process, results, and imbalances that occur in the learning implementation. An evaluation model innovation was initiated through this research in the form of a modification of two educational evaluation models. Those models are CSE-UCLA and Discrepancy. Based on those conditions, the main objective of this research was to demonstrate the existence of a new evaluation model design in education which was a modification of the CSE-UCLA evaluation model and the Discrepancy evaluation model. Specifically, this evaluation model design can be used to determine the effectiveness of the one education activity namely the synchronous learning implementation at vocational universities. The research method used to achieve the objectives of this research was the development method by the Borg and Gall model development design. Five stages of development become the focus of this research, included: research and field data collection, research planning, design development, initial trials, and main product revision. The location of this research was conducted in several vocational universities in the North Bali area (Indonesia). Subjects involved in the initial trials toward this evaluation model design were 20 people. The tools used to conduct the initial trials were questionnaires. The technique used to analyze the data of initial trial results was descriptive quantitative by comparing the percentage of the initial trial results with the standard percentage of the effectiveness level of modified model design. This research results indicate that the evaluation model design was categorized as effective by an effectiveness level was $81.93 \%$. The implication of this research results was the existence of a new design of the educational evaluation model. This design combines two evaluation models to produce good functionality integration in determining the effectiveness level of the synchronous learning implementation in all universities generally and in vocational universities in Bali particularly.
\end{abstract}

\section{Keywords:}

Modification;

CSE-UCLA;

Discrepancy;

New Evaluation Model

\section{Article History:}

$\begin{array}{llll}\text { Received: } & 27 & \text { July } & 2021 \\ \text { Revised: } & 05 & \text { October } & 2021 \\ \text { Accepted: } & 19 & \text { October } & 2021 \\ \text { Published: } & 01 & \text { December } & 2021\end{array}$

\section{1- Introduction}

Synchronous learning during the Covid-19 pandemic is the most appropriate learning strategy to use so that educational activities continue to run optimally. It is done to minimize crowds during the learning process. Those statements are following the opinion of several researchers included: Coman et al. [1], Fatoni et al. [2], Mardiah [3], Murphy [4], and Yulia [5], who in principle stated that the synchronous strategy is very appropriate to use in learning during a Covid-19 pandemic because it can reduce the occurrence of crowds. Synchronous learning facilitates face-toface learning between lecturers and students through internet technology-based virtual rooms. Many internet technology-based platforms provide facilities for synchronous learning. Some of the famous platforms included: Zoom, Meet Google, and Webex [6-9]. However, not all of those platforms can make the synchronous learning process effective in viewed from context domain, input domain, socialization process domain, implementation process domain, results domain, and imbalances domain.

*CONTACT: hendra.divayana@undiksha.ac.id

DOI: http://dx.doi.org/10.28991/esj-2021-01321

(C) 2021 by the authors. Licensee ESJ, Italy. This is an open access article under the terms and conditions of the Creative Commons Attribution (CC-BY) license (https://creativecommons.org/licenses/by/4.0/). 
Based on the limitations of those platforms, it is necessary to carry out an in-depth evaluation to determine the effectiveness of synchronous learning implementation. Many educational evaluation models were able to be used to evaluate the effectiveness of synchronous learning, included: CSE-UCLA model [10], Countenance model [11], Discrepancy model [12], Kirkpatrick model [13], Goal Oriented Evaluation model [14], and CIPP (Context-InputProcess-Product) model [15]. From those several models, none of them were able to show the level of effectiveness of synchronous learning completely and thoroughly based on the context domain, input domain, socialization process domain, creation/implementation process domain, results domain, and imbalances domain. That statement is following the research results of Tripathi and Bansal [16], Esgaiar and Foster's research [17], and Mubayrik's research [18], which principally stated that each evaluation model has its evaluation component and its indicator characteristics according to the object being evaluated. Certainly, between one evaluation model and another evaluation model it has its advantages and disadvantages. Based on that, it can be generalization that no evaluation model can show the overall effectiveness of object evaluated from various domains, so modifications to the evaluation models are needed.

Therefore, it was necessary to modify the evaluation model to produce an appropriate evaluation model used in evaluating the effectiveness of synchronous learning implementation. One of the efforts was a modification of the CSE-UCLA model with the Discrepancy model. Principally, the CSE-UCLA (Center for the Study of EvaluationUniversity of California in Los Angeles) model is an evaluation model that has five evaluation dimensions (system assessment, program planning, program implementation, program improvement, program certification) and is suitable for use to evaluate service programs that help human life, included: e-learning, blended learning, e-government, library programs, and so on $[19,20]$. Principally, the Discrepancy model is an evaluation model that functions to determine the level of gaps that occur in the implementation of a program/service by comparing evaluation results with evaluation standards which refer to four evaluation components, included: definition, installation, process, and product [21, 22].

The reason for making modifications to those two evaluation models is because they have evaluation components that have similar functionality and complement each other. If those two models are combined, it can be used to completely and thoroughly evaluate the synchronous learning implementation in the viewed of the context domain, input domain, socialization process domain, implementation process domain, results domain, and imbalances domain. The context domain can be evaluated using the system assessment component of the CSE-UCLA model and the definition component of the Discrepancy model. The input domain can be evaluated using the program planning component of the CSE-UCLA model and the installation component of the Discrepancy model. The socialization process domain can't be evaluated using the Discrepancy model component, but it can be evaluated using the program implementation component of the CSE-UCLA model. The implementation process domain can be evaluated using the program improvement component of the CSE-UCLA model and the process component of the Discrepancy model. The results domain can be evaluated using the program certification component of the CSE-UCLA model and the product component of the Discrepancy model that shows the effectiveness level of synchronous learning implementation. The imbalances domain can't be evaluated using the component of the CSE-UCLA model, but it can be evaluated using the product component of the Discrepancy model that shows the imbalance in the synchronous learning implementation.

The similarity in the functionality of those two evaluation models is indicated by the existence of components are owned by each model which can be used to evaluate the context domain, input domain, implementation process domain, and results domain. The functionality which complementary of the two evaluation models is indicated by the existence of the CSE-UCLA component which is used to complements the limitation of the Discrepancy components' function and otherwise, the Discrepancy component which complements the limitation of the CSE-UCLA components' function. The program implementation component of the CSE-UCLA model complements the limitation of the Discrepancy components' function which is unable to evaluate the socialization process domain. The product component in the Discrepancy model which specifically functions to evaluate the imbalance level can be used to complement the limitation of the CSE-UCLA components' function which is unable to evaluate the imbalances domain. The importance of making modifications to the two models raises questions in this research. The research question: "How is the modified form of the CSE-UCLA model and the Discrepancy model as new evaluation model in education that used to determine the effectiveness level of synchronous learning?"

Some of the results and limitations of the previous research were used to show this research position and its contributions. The contributions of this research were used as a solution to the problem solving of the previous research. Research conducted by Mohmmed et al. [23] showed the use of the CIPP model in evaluating the effectiveness of synchronous and asynchronous-based distance learning during the Coronavirus pandemic. The research results of Mohmmed et al. only were able to show the effectiveness of the context domain, input domain, process domain, and product domain. The research results of Mohmmed et al. weren't able to show the socialization process of the existence of synchronous learning and weren't able to show imbalances in the implementation of this learning. The research was conducted by Sudarwati \& Rukminingsih [24] showed the use of the Discrepancy evaluation model to measure the effectiveness level of synchronous e-learning. The research results of Sudarwati \& Rukminingsih only were able to show the imbalances that occur in the implementation of synchronous e-learning but weren't able to show the details of the mechanisms and processes of socializing the existence of synchronous elearning to the schools' community. Divayana et al.'s research [25] showed the use of the CSE-UCLA model to 
evaluate the learning effectiveness of expert system subjects based on mobile technology. The results of Divayana et al.'s research indicated the effectiveness of the learning implementation of expert system subjects from the context domain, input domain, process domain, results domain, and also the socialization process domain. However, the results of Divayana et al.'s research weren't able to show imbalances in the learning process. The efforts to facilitate understanding toward some of the results of previous research that background this research, it is necessary to show through a research roadmap. The roadmap for this research can be seen in Figure 1.

\begin{tabular}{|c|c|c|c|c|}
\hline $\begin{array}{l}2018 \\
\text { Research Title: } \\
\text { - Empowerment of the } \\
\text { CSE-UCLA Model in } \\
\text { the Evaluation of the } \\
\text { Blended Learning } \\
\text { Program at SMA } \\
\text { Negeri } 1 \text { Ubud } \\
\text { By: Suyasa et al. [26] } \\
\text { Research Results: } \\
\text { - The evaluation of } \\
\text { blended learning } \\
\text { program } \\
\text { implementation at } \\
\text { SMA Negeri } 1 \text { Ubud } \\
\text { had gone well. It was } \\
\text { indicated by the } \\
\text { evaluation results of } \\
\text { each evaluation } \\
\text { component of the } \\
\text { CSE-UCLA model } \\
\text { that had shown a } \\
\text { good category and } \\
\text { specifically excellent } \\
\text { on the system } \\
\text { assessment } \\
\text { component. } \\
\text { Research Constraints: } \\
\text { - Difficulty to } \\
\text { determine the most } \\
\text { dominant aspect and } \\
\text { component in } \\
\text { influencing and } \\
\text { determining the } \\
\text { optimization of } \\
\text { program } \\
\text { implementation. }\end{array}$ & $\begin{array}{l}\text { R019 } \\
\text { Research Title: } \\
\text { Program Evaluation: } \\
\text { Implementation of } \\
\text { Tourism Village } \\
\text { Development } \\
\text { By: Sudirtha et al. [27] } \\
\text { Research Results: } \\
\text { - The evaluation study } \\
\text { of the Sambangan } \\
\text { tourism village } \\
\text { development program } \\
\text { with the CSE-UCLA } \\
\text { evaluation model } \\
\text { approach was able to } \\
\text { provide several new } \\
\text { recommendations in } \\
\text { determining program } \\
\text { optimization. } \\
\text { Research Constraints: } \\
\text { - Research results had } \\
\text { not shown details } \\
\text { about the priority } \\
\text { aspects that } \\
\text { determine the } \\
\text { program } \\
\text { optimization. }\end{array}$ & $\begin{array}{l}\text { Research Title: } \\
\text { ANEKA Value-Based } \\
\text { Countenance } \\
\text { Evaluation Model } \\
\text { Integrated with the } \\
\text { Tri Hita Karana } \\
\text { Concept to Improve } \\
\text { the Characters and } \\
\text { Quality of Computer } \\
\text { Learning for ICT } \\
\text { Vocational Schools' } \\
\text { Students in Bali } \\
\text { By: Divayana, et al. [28] } \\
\text { Research Results: } \\
\text { - Research results } \\
\text { showed priority } \\
\text { aspects that cause an } \\
\text { increase in the } \\
\text { character and quality } \\
\text { of computer learning } \\
\text { for ICT Vocational } \\
\text { Schools' students in } \\
\text { Bali. } \\
\text { Research Constraints: } \\
\text { - Research results had } \\
\text { not shown details } \\
\text { about the imbalances } \\
\text { that occur in the } \\
\text { learning } \\
\text { implementation. }\end{array}$ & $\begin{array}{l}\text { Research Title: } \\
\text { - Modification of CSE- } \\
\text { UCLA and } \\
\text { Discrepancy as a New } \\
\text { Evaluation Model in } \\
\text { Education } \\
\text { By: Suyasa and Divayana } \\
\text { Research Purposes: } \\
\text { - Realize of the CSE- } \\
\text { UCLA evaluation } \\
\text { model design was } \\
\text { modified with the } \\
\text { Discrepancy model, so } \\
\text { it was able to show the } \\
\text { imbalances that occur } \\
\text { in the learning } \\
\text { implementation. } \\
\text { Research Results that } \\
\text { Expected: } \\
\text { - CSE-UCLA evaluation } \\
\text { model design modified } \\
\text { with Discrepancy } \\
\text { model. }\end{array}$ & $\begin{array}{l}\text { Modification of the } \\
\text { CSE-UCLA Model } \\
\text { and Discrepancy } \\
\text { Model to Support } \\
\text { Evaluation of the } \\
\text { Effectiveness of the } \\
\text { Implementation of } \\
\text { Synchronous } \\
\text { Learning at } \\
\text { Vocational } \\
\text { Universities }\end{array}$ \\
\hline
\end{tabular}

Figure 1. Research Roadmap.

Based on the visualization of Figure 1, it appears that the results of this research were in the form of a modified CSE-UCLA evaluation model design with the Discrepancy model. The presence of this model design is an answer to several obstacles from previous studies starting from 2018-2020. The evaluation model design resulted from this research can be used as a description of the process carried out in evaluation activities toward the effectiveness of the synchronous learning implementation at vocational universities. 


\section{2- Material and Methods}

\section{2-1- Research Goal, Research Approach, and Research Method}

The goal of this research was to determine the modified form of the CSE-UCLA model and the Discrepancy model used to determine the effectiveness level of synchronous learning. The effort was made to achieve that goal was to conduct research using a development approach. The development method utilized in this research was based on the development design of the Borg and Gall model which consists of ten stages [29,30]. Those ten stages of development can be seen in Figure 2.

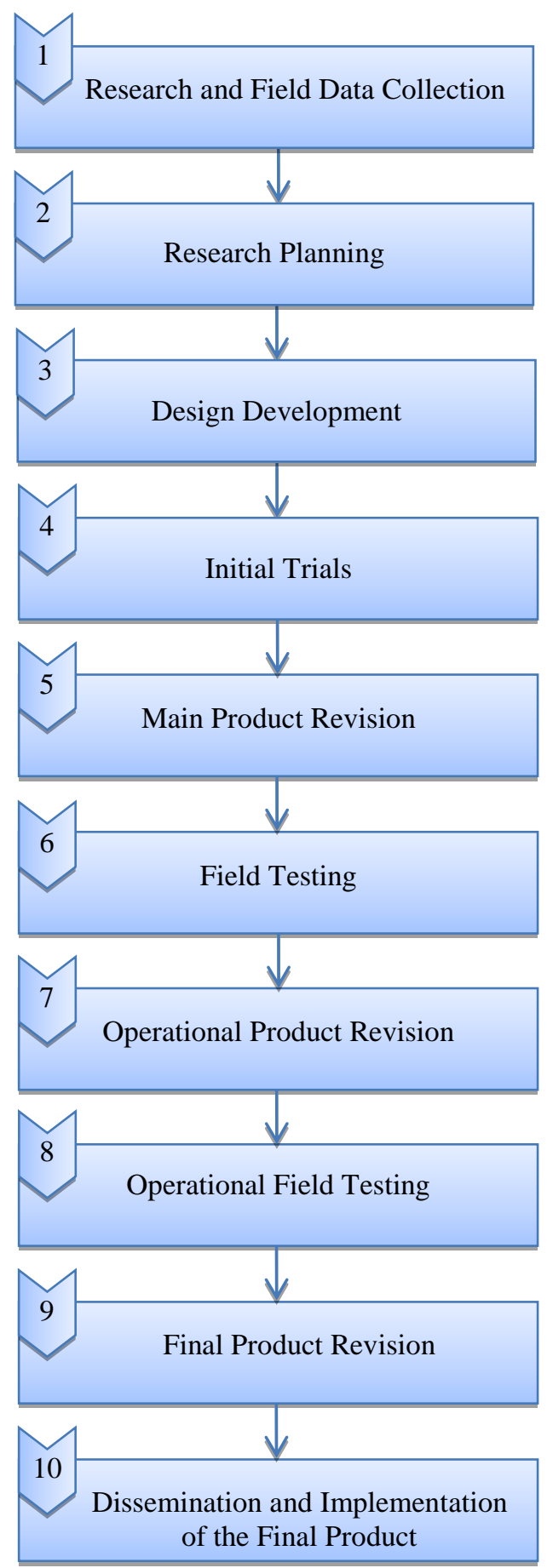

Figure 2. The Research Stages that Refer to the Borg and Gall Design.

Specifically for research in 2021 was conducted several development stages, included: the stage of research and field data collection related to the CSE-UCLA and Discrepancy concepts which were used as the knowledge base to make evaluation model design, stage of research planning, stage of design development, stage of initial trials, and the stage of main product revision toward the evaluation model design which is the results of modification from the CSEUCLA model and Discrepancy model. 


\section{2-2- Research Location, Sample, and Technique of Data Collection}

This research was conducted in several vocational universities in Bali Province, especially in North Bali. The reason for this research location in the North Bali area was because this area is the center of education in Bali, with the characteristics of students who came from various regions in Indonesia. Besides, access to information technology in North Bali is not superior compare with South Bali. However, this precisely makes it easier to determine the effectiveness of synchronous learning. If the area that has limited information technology can effectively carry out synchronous learning, so logically, the area that already has superior facilities and access to information technology, certain can carry out synchronous learning more effectively.

Subjects in this research were determined using a purposive sampling technique. Purposive sampling was conducted by determining the parties directly related to the implementation of synchronous learning at vocational universities in North Bali. The reason for using this purposive sampling technique was because this technique was very appropriate to be used to obtain complete information from parties who had knowledge and experience of synchronous learning [31,32]. Subjects involved in this research were three research members and three field workers, especially at the stage of research and field data collection, research planning, and design development. The subjects involved in the initial trials of the evaluation model design were ten evaluators and ten lecturers in the field of vocational from several universities in North Bali. The subjects involved in the main product revision were three members of the research team in this research.

The data collection tools of the initial trial results toward the model design were questionnaires. The questionnaires consist of 15 questions. Each question was assessed using five types of assessment scores that follow the Likert scale. A score of 5 means excellent, a score of 4 means good, a score of 3 means enough, a score of 2 means less, and a score of 1 means poor [33-35]. The content validity tests of the questionnaire questions were carried out by two educational evaluation experts. The formula used to content validity tests of the questionnaire questions was the Gregory formula. The Gregory formula can be seen in Equation 1 [36-38].

Content Validity $=D /(A+B+C+D)$

Notes: $A=$ cell indicating disagreement between the two judges; $B$ and $C=$ cells indicating the difference in views between the judges; $D=$ cell indicating valid agreement between the two judges.

\section{2-3- Analyzing of Data}

The analysis technique of the questionnaire questions was carried out by comparing the results of the content validity tests with the content validity score standards which refer to the Guilford category. The categorization of content validity refers to Guilford [39,40], included: a validity score of 0.80 to 1.00 means very high validity, 0.60 to 0.80 means high validity, 0.40 to 0.60 means sufficient validity, 0.20 to 0.40 means low validity, 0.00 to 0.20 means very low validity, a validity score $<0.00$ means invalid.

The analysis technique used in analyzing the trial results of the modified evaluation model design was quantitative descriptive. This technique was done by comparing the percentage of trial results with the percentage of the effectiveness standards of the modified evaluation model design. The formula was used to calculate the percentage of trial results follows Equation 2 [41], while the percentage of the effectiveness standards of the modified evaluation model design follows the percentage range of effectiveness scores. The percentage score in the range of $0 \%$ to $39 \%$ means poor, the percentage score in the range of $40 \%$ to $64 \%$ which means less, the percentage score in the range of $65 \%$ to $79 \%$ means enough, the percentage score in the range $80 \%$ to $89 \%$ means effective, and the percentage score in the range of $90 \%$ to $100 \%$ means excellent [42].

Percentage of Trial Results toward Design $=\left(f \times N^{-1}\right) \times 100 \%$

Notes: $f=$ total of acquisition values; $N=$ total of maximum scores.

\section{3- Results and Discussion}

The results obtained at the stage of research and field data collection were data related to components and aspects of the CSE-UCLA evaluation model and the Discrepancy evaluation model which were used as references in evaluating the implementation of synchronous learning. The components and aspects of the CSE-UCLA evaluation model completely can be seen in Table 1, while the components and aspects of the Discrepancy evaluation model can be seen in Table 2. 
Table 1. Components and Aspects of the CSE-UCLA Evaluation Model as References for Evaluating the Implementation of Synchronous Learning at Vocational Universities in North Bali.

\begin{tabular}{|c|c|c|}
\hline $\begin{array}{l}\text { Evaluation } \\
\text { Components }\end{array}$ & $\begin{array}{l}\text { Codes of } \\
\text { Aspects }\end{array}$ & Evaluation Aspects \\
\hline \multirow{3}{*}{$\begin{array}{c}\text { System } \\
\text { Assessment }\end{array}$} & AP1 & The purpose of synchronous learning implementation \\
\hline & AP2 & Support from the academic community in each vocational university in North Bali \\
\hline & AP3 & Regulations that support the implementation of synchronous learning \\
\hline \multirow{7}{*}{$\begin{array}{l}\text { Program } \\
\text { Planning }\end{array}$} & AP4 & The readiness of students in providing internet data packages \\
\hline & AP5 & The readiness of students in providing computer hardware to support synchronous learning \\
\hline & AP6 & The student's ability to operate the platform used in implementing the synchronous learning \\
\hline & AP7 & The readiness of lecturers in providing internet data packages \\
\hline & AP8 & The lecturers' ability to provide interesting teaching materials and suitable for use in synchronous learning \\
\hline & AP9 & The readiness of lecturers in providing computer hardware to support synchronous learning \\
\hline & AP10 & The lecturers' ability to operate the platform used in implementing the synchronous learning \\
\hline \multirow{3}{*}{$\begin{array}{c}\text { Program } \\
\text { Implementation }\end{array}$} & AP11 & Socialization of the existence of synchronous learning by lecturers through distributing platform links to students \\
\hline & AP12 & Socialization of links of teaching materials to students by lecturers before or after synchronous learning implementation \\
\hline & AP13 & Socialization of the guideline of synchronous learning implementation to students by the lecturers \\
\hline \multirow{3}{*}{$\begin{array}{c}\text { Program } \\
\text { Improvement }\end{array}$} & AP14 & The mechanism for making interesting teaching materials in digital format \\
\hline & AP15 & The mechanism for creating an account in the platform that is used to support synchronous learning \\
\hline & AP16 & Mechanism of synchronous learning implementation \\
\hline \multirow{4}{*}{$\begin{array}{c}\text { Program } \\
\text { Certification }\end{array}$} & AP17 & Students' satisfaction in the ease to operate the platform that is used to support the synchronous learning implementation \\
\hline & AP18 & Lecturers' satisfaction in the ease to operate the platform that is used to support the synchronous learning implementation \\
\hline & AP19 & The safety of teaching materials that are distributed to students in synchronous learning \\
\hline & AP20 & $\begin{array}{l}\text { The satisfaction of students and lecturers in the interactions and communications that occur through the platform which } \\
\text { used to support the synchronous learning implementation }\end{array}$ \\
\hline
\end{tabular}

Table 2. Components and Aspects of the Discrepancy Evaluation Model as References for Evaluating the Implementation of Synchronous Learning at Vocational Universities in North Bali.

\begin{tabular}{|c|c|c|}
\hline $\begin{array}{l}\text { Evaluation } \\
\text { Components }\end{array}$ & $\begin{array}{l}\text { Codes of } \\
\text { Aspects }\end{array}$ & Evaluation Aspects \\
\hline \multirow{3}{*}{ Definition } & AD1 & Vision, mission, and objectives of synchronous learning \\
\hline & AD2 & Support from the academic community at each vocational university in North Bali for implementing synchronous learning \\
\hline & AD3 & The law legality of implementing synchronous learning \\
\hline \multirow{3}{*}{ Installation } & AD4 & The readiness of students and lecturers in implementing synchronous learning \\
\hline & AD5 & The readiness of facilities and infrastructures to support synchronous learning \\
\hline & AD6 & The readiness of the management team of system/platform in support synchronous learning \\
\hline \multirow{3}{*}{ Process } & AD7 & Procedures for lecturers in making digital format teaching materials that are distributed to students \\
\hline & AD8 & $\begin{array}{l}\text { Procedures for creating an account in the platform for lecturers and students so that they can access the platform which is } \\
\text { used for the synchronous learning process }\end{array}$ \\
\hline & AD9 & Procedures for implementing synchronous learning so that it runs effectively \\
\hline \multirow{5}{*}{ Product } & AD10 & The satisfaction of students and lecturers toward the ease to operate a platform for synchronous learning \\
\hline & AD11 & The satisfaction of students and lecturers toward the access speed into the platform is used in synchronous learning \\
\hline & AD12 & The security level of digital format teaching materials that are distributed by lecturers to students \\
\hline & AD13 & $\begin{array}{l}\text { The satisfaction of students and lecturers in communicating and interacting through the platform that supports } \\
\text { synchronous learning }\end{array}$ \\
\hline & $\mathrm{AD} 14$ & Imbalances score of synchronous learning implementation \\
\hline
\end{tabular}

Table 1 shows the existence of 20 evaluation aspects of the CSE-UCLA model. Three aspects of the system assessment component are used to evaluate things related to objectives, support, and regulations in implementing synchronous learning. Seven aspects of the program planning component are used to evaluate things related to infrastructure readiness and the readiness of lecturers' ability and students' ability in implementing synchronous learning. Three aspects of the program implementation component are used to evaluate things related to the socialization of synchronous learning implementation. Three aspects of the program improvement component are used 
to evaluate things related to the mechanism and process of implementing synchronous learning. Four aspects of the program certification component are used to evaluate things related to the results of implementing synchronous learning is viewed from the satisfaction of students and lecturers.

Table 2 shows the existence of 14 evaluation aspects of the Discrepancy model. Three aspects of the definition component are used to evaluate things related to the vision, mission, goals, support, and legality of implementing synchronous learning. Three aspects of the installation component are used to evaluate things related to infrastructure readiness, the readiness of lecturers and students, and the readiness of the systems/platforms management team used in implementing synchronous learning. Three aspects of the process component are used to evaluate things related to the implementation of synchronous learning. Four aspects of the product component are used to evaluate things related to satisfaction results and the inequality score of the synchronous learning implementation.

The results obtained at the planning stage of this research were data about the description of activities, the number of personnel who were involved, and the completion time of the CSE-UCLA model design modified with the Discrepancy model. The data of research planning completely can be seen in Table 3.

Table 3. Data of the Completion Planning for the Design that Modification Results of the CSE-UCLA Model and the Discrepancy Model.

\begin{tabular}{|c|c|c|c|}
\hline Activities & $\begin{array}{l}\text { Time } \\
\text { (Days) }\end{array}$ & $\begin{array}{l}\text { Number of } \\
\text { Personnel }\end{array}$ & Personnel Details \\
\hline $\begin{array}{l}\text { Describe the components and aspects of the CSE-UCLA } \\
\text { evaluation model }\end{array}$ & 1 & 6 & Three research members and three field workers \\
\hline $\begin{array}{l}\text { Describe the components and aspects of the Discrepancy } \\
\text { evaluation model }\end{array}$ & 1 & 6 & Three research members and three field workers \\
\hline $\begin{array}{l}\text { Design an evaluation model which was a modification of the } \\
C S E-U C L A \text { evaluation model and Discrepancy evaluation model }\end{array}$ & 7 & 6 & Three research members and three field workers \\
\hline Initial trials of the evaluation model design & 14 & 20 & $\begin{array}{l}\text { Ten evaluators and ten lecturers at vocational } \\
\text { universities in North Bali }\end{array}$ \\
\hline Revision of the initial trial results of the evaluation model design & 7 & 3 & Three research members \\
\hline
\end{tabular}

Table 3 shows five important activities planned to finalize the design of the CSE-UCLA model that modification with the Discrepancy model. The total time planned to complete the design was 30 days. The total numbers of personnel who were planned to be involved in completing the design were 26 people, included: three researchers, three field staff, ten lecturers, and ten evaluators.

The results obtained at the stage of design development were the modified design of the CSE-UCLA model and the Discrepancy model. The design of this model showed an innovative evaluation model that can be used to determine the synchronous learning effectiveness in vocational universities. The model design intended completely can be seen in Figure 3.

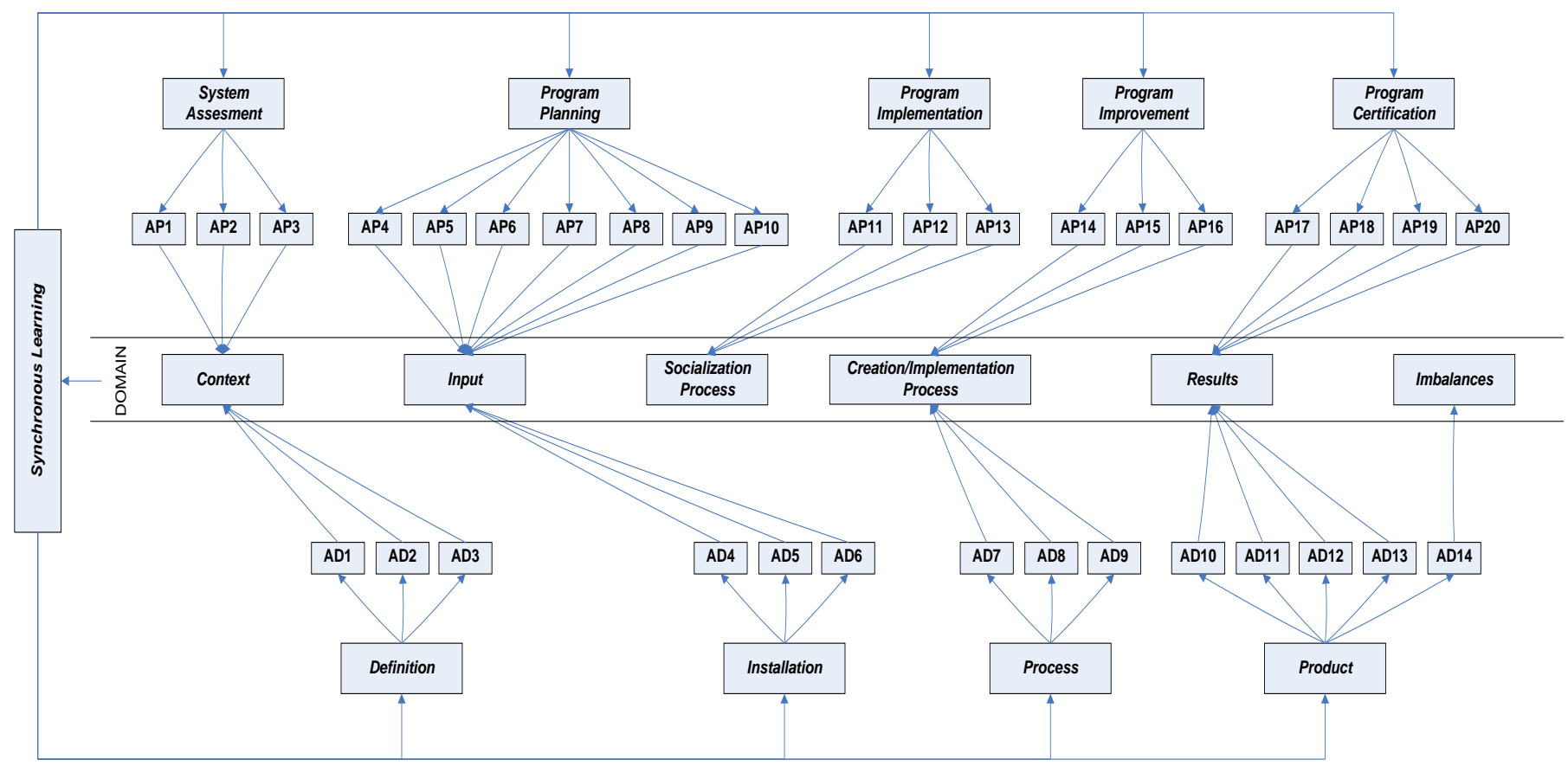

Figure 3. The Design that Modified Results of the CSE-UCLA Model and the Discrepancy Model to Evaluate the Effectiveness of Synchronous Learning at Vocational Universities. 
The implementation of synchronous learning can be said to be effective if the effectiveness level in the determinants of effectiveness (context, input, socialization process, creation/implementation process, results, and imbalances) is categorized as effective. The effort that was made to determine the effectiveness level of synchronous learning was determined using a modification of the CSE-UCLA model and the Discrepancy model. The CSE-UCLA model has five evaluation components, included: 1) system assessment, 2) program planning, 3) program implementation, 4) program improvement, and 5) program certification.

System assessment is an evaluation component that provides information about the state or position of the system/program being evaluated. Program planning is an evaluation component that helps select certain programs that are likely to be successful in fulfilling program needs. Program implementation is an evaluation component that provides information on whether the program has been introduced to certain groups as planned. Program improvement is an evaluation component that provides information about how the program is functioning or working, whether it leads to certain achievements. Program certification is an evaluation that provides information about the value or results and benefits of the program [19].

The CSE-UCLA model has 20 evaluation aspects. Three aspects (AP1 to AP3) are used to evaluate the context domain, seven aspects (AP4 to AP10) are used to evaluate the input domain, three aspects (AP11 to AP13) are used to evaluate the socialization process domain, three aspects (AP14 to AP16) are used to evaluate the domain of the creation/implementation process, four aspects (AP17 to AP20) are used to evaluate the outcome domain. A description of all evaluation aspects of the CSE-UCLA model had been shown previously in Table 1.

The Discrepancy model has four evaluation components, included: 1) definition, 2) installation, 3) process, and 4) product. The definition is an evaluation component to assess the completeness and consistency of the program design. The installation is an evaluation component to assess the suitability of program installations. The process is an evaluation component to assess the extent to which the program is implemented. The product is an evaluation component to assess the results of program implementation [21, 24].

The Discrepancy model has 14 evaluation aspects. Three aspects (AD1 to AD3) are used to evaluate the context domain, three aspects (AD4 to AD6) are used to evaluate the input domain, three aspects (AD7 to AD9) are used to evaluate the creation/implementation process domain, four aspects (AD10 to AD13) are used to evaluate the product domain, and one aspect (AD14) is used to evaluate the imbalances domain. A description of all evaluation aspects of the Discrepancy model had been shown previously in Table 2. The CSE-UCLA model does not have an aspect that is used to evaluate the imbalances domain, but it has been assisted by the AD14 aspect of the Discrepancy model to evaluate the imbalances domain. The Discrepancy model does not have an aspect that is used to evaluate the domain of the socialization process, but it has been assisted through the AP11 to AP13 aspects of the CSE-UCLA model to evaluate the domain of socialization process. Recommendations for the improvement of the synchronous learning process are given based on the constraints found in all the determinants of the effectiveness of synchronous learning implementation.

The results obtained at the stage of initial trials were used as the basis for making improvements to the modified design of the CSE-UCLA and Discrepancy models. The results of the initial trials were in the form of quantitative and qualitative data. The quantitative data showed the effectiveness level percentage of the evaluation model design modified, while the qualitative data showed several arguments given by the respondents as the basis for improvements to the modified design. The details regarding the quantitative data from the initial trial results can be seen in Table 4 , while the qualitative data from the initial trial results can be seen in Table 5.

Table 4. Results of Initial Trials toward the Design of CSE-UCLA Model that Modification with Discrepancy Model.

\begin{tabular}{|c|c|c|c|c|c|c|c|c|c|c|c|c|c|c|c|c|c|}
\hline \multirow{2}{*}{ Respondents } & \multicolumn{15}{|c|}{ Items- } & \multirow{2}{*}{$\sum$} & \multirow{2}{*}{$\begin{array}{l}\text { Percentage of Effectiveness } \\
(\%)\end{array}$} \\
\hline & 1 & 2 & 3 & 4 & 5 & 6 & 7 & 8 & 9 & 10 & 11 & 12 & 13 & 14 & 15 & & \\
\hline Respondent- 1 & 5 & 4 & 5 & 4 & 5 & 5 & 5 & 5 & 4 & 4 & 4 & 5 & 4 & 5 & 4 & 59 & 78.67 \\
\hline Respondent-2 & 4 & 4 & 4 & 4 & 5 & 4 & 5 & 5 & 5 & 5 & 4 & 4 & 5 & 5 & 5 & 61 & 81.33 \\
\hline Respondent-3 & 5 & 5 & 4 & 4 & 5 & 4 & 4 & 4 & 4 & 4 & 4 & 5 & 4 & 4 & 5 & 62 & 82.67 \\
\hline Respondent-4 & 5 & 4 & 5 & 4 & 4 & 4 & 4 & 4 & 5 & 5 & 4 & 4 & 5 & 4 & 4 & 62 & 82.67 \\
\hline Respondent-5 & 5 & 5 & 4 & 5 & 5 & 4 & 5 & 4 & 4 & 4 & 4 & 5 & 4 & 4 & 5 & 61 & 81.33 \\
\hline Respondent- 6 & 4 & 4 & 5 & 4 & 4 & 4 & 5 & 4 & 5 & 5 & 4 & 4 & 5 & 4 & 4 & 60 & 80.00 \\
\hline Respondent-7 & 5 & 4 & 4 & 5 & 5 & 4 & 4 & 4 & 4 & 4 & 4 & 5 & 4 & 4 & 5 & 63 & 84.00 \\
\hline Respondent- 8 & 4 & 4 & 5 & 4 & 4 & 4 & 5 & 4 & 5 & 5 & 4 & 4 & 5 & 4 & 4 & 62 & 82.67 \\
\hline Respondent-9 & 5 & 4 & 4 & 4 & 5 & 4 & 4 & 4 & 4 & 4 & 4 & 5 & 4 & 4 & 5 & 61 & 81.33 \\
\hline Respondent-10 & 4 & 4 & 5 & 4 & 4 & 4 & 5 & 5 & 4 & 5 & 4 & 4 & 4 & 5 & 4 & 61 & 81.33 \\
\hline Respondent-11 & 5 & 4 & 4 & 4 & 5 & 4 & 4 & 5 & 5 & 5 & 5 & 5 & 4 & 4 & 4 & 64 & 85.33 \\
\hline
\end{tabular}




\begin{tabular}{lllllllllllllllllll}
\hline \multirow{2}{*}{ Respondents } & \multicolumn{1}{c}{} & $\mathbf{1}$ & $\mathbf{2}$ & $\mathbf{3}$ & $\mathbf{4}$ & $\mathbf{5}$ & $\mathbf{6}$ & $\mathbf{7}$ & $\mathbf{8}$ & $\mathbf{9}$ & $\mathbf{1 0}$ & $\mathbf{1 1}$ & $\mathbf{1 2}$ & $\mathbf{1 3}$ & $\mathbf{1 4}$ & $\mathbf{1 5}$ & & \multicolumn{2}{c}{$\begin{array}{c}\text { Percentage of Effectiveness } \\
(\boldsymbol{\%})\end{array}$} \\
\hline Respondent-12 & 4 & 5 & 5 & 4 & 4 & 5 & 4 & 4 & 4 & 5 & 5 & 4 & 4 & 5 & 4 & 62 & & 82.67 \\
Respondent-13 & 5 & 4 & 4 & 4 & 4 & 4 & 4 & 5 & 4 & 4 & 4 & 5 & 4 & 4 & 5 & 61 & & 81.33 \\
Respondent-14 & 4 & 5 & 5 & 4 & 4 & 5 & 4 & 4 & 4 & 4 & 4 & 5 & 5 & 5 & 4 & 64 & & 85.33 \\
Respondent-15 & 5 & 4 & 4 & 4 & 5 & 4 & 4 & 5 & 4 & 5 & 4 & 4 & 5 & 5 & 5 & 61 & & 81.33 \\
Respondent-16 & 4 & 5 & 5 & 5 & 4 & 4 & 5 & 4 & 5 & 4 & 4 & 5 & 5 & 4 & 4 & 59 & & 78.67 \\
Respondent-17 & 5 & 5 & 4 & 4 & 5 & 4 & 4 & 5 & 4 & 5 & 4 & 4 & 4 & 5 & 4 & 62 & & 82.67 \\
Respondent-18 & 5 & 5 & 5 & 5 & 4 & 4 & 5 & 4 & 5 & 4 & 4 & 5 & 4 & 5 & 4 & 61 & & 81.33 \\
Respondent-19 & 4 & 4 & 5 & 4 & 5 & 4 & 4 & 4 & 4 & 5 & 4 & 4 & 4 & 4 & 5 & 62 & 82.67 \\
Respondent-20 & 5 & 5 & 4 & 5 & 4 & 4 & 5 & 4 & 4 & 4 & 4 & 5 & 4 & 4 & 5 & 61 & 81.33 \\
\hline
\end{tabular}

Table 4 shows the average percentage of effectiveness obtained from the initial trials conducted by 20 respondents toward the modified design of the CSE-UCLA and Discrepancy models. Fifteen question items were used as a basis for evaluating that design. Fifteen questions were used to obtain data from the initial trial results. Item-1 is a question about the availability of evaluation aspects in the system assessment component of the CSE-UCLA model. Item-2 is a question about the availability of evaluation aspects in the program planning component of the CSE-UCLA model. Item-3 is a question about the availability of evaluation aspects in the program implementation component of the CSEUCLA model. Item-4 is a question about the availability of evaluation aspects in the program improvement component of the CSE-UCLA model. Item-5 is a question about the availability of evaluation aspects in the program certification component of the CSE-UCLA model. Item-6 is a question about the availability of evaluation aspects in the defining component of the Discrepancy model. Item-7 is a question about the availability of evaluation aspects in the installation component of the Discrepancy model. Item-8 is a question about the availability of evaluation aspects in the process component of the Discrepancy model. Item-9 is a question about the availability of evaluation aspects in the product component of the Discrepancy model. Item-10 is a question about the suitability of the evaluation aspects of the CSE-UCLA and Discrepancy models that are used to evaluate the context domain. Item-11 is a question about the suitability of the evaluation aspects of the CSE-UCLA and Discrepancy models that are used to evaluate the input domain. Item-12 is a question about the suitability of the evaluation aspects of the CSE-UCLA model that is used to evaluate the socialization process domain. Item-13 is a question about the suitability of the evaluation aspects of the CSE-UCLA and Discrepancy models that are used to evaluate the domain of the creation/implementation process. Item-14 is a question about the suitability of the evaluation aspects of the CSE-UCLA and Discrepancy models that are used to evaluate the domain of results. Item-15 is a question about the suitability of the evaluation aspects of the Discrepancy model that is used to evaluate the domain of imbalances.

Table 5 shows six important suggestions given by respondent-2, respondent-10, respondent-14, respondent-16, respondent-18, and respondent-20. All of those suggestions were very well used as a basis for improvements to the design of the CSE-UCLA model that modification with the Discrepancy model. Based on several arguments given by respondents as shown in Table 5, a revision was made to the modified design of the CSE-UCLA and Discrepancy models. The revised design can be seen in Figure 4.

Table 5. Respondents' Arguments toward the Design of CSE-UCLA Model that Modification with Discrepancy Model.

\begin{tabular}{cl}
\hline Respondents & \multicolumn{1}{c}{ Arguments } \\
\hline Respondent-2 & $\begin{array}{l}\text { It was necessary to put a mark or lines that distinguish between the components and aspects of the evaluation in both the CSE- } \\
\text { UCLA model and the Discrepancy model }\end{array}$ \\
Respondent-10 & $\begin{array}{l}\text { It was necessary to show the name of the } C S E-U C L A \text { evaluation model and the Discrepancy model to cover each component } \\
\text { and the aspects shown in the design }\end{array}$ \\
Respondent-14 & $\begin{array}{l}\text { Evaluation components of Discrepancy and } C S E \text { - } U C L A \text { need to be colored differently to make it easier to see the process flow } \\
\text { that occurs }\end{array}$ \\
Respondent-16 & $\begin{array}{l}\text { Each component of the evaluation model must be given a back and forth arrow which indicates that one component to another } \\
\text { was connected and related to one another. }\end{array}$ \\
Respondent-18 & $\begin{array}{l}\text { It was necessary to provide dividing lines to distinguish between the components and aspects of the evaluation between the two } \\
\text { evaluation models. }\end{array}$ \\
\hline
\end{tabular}




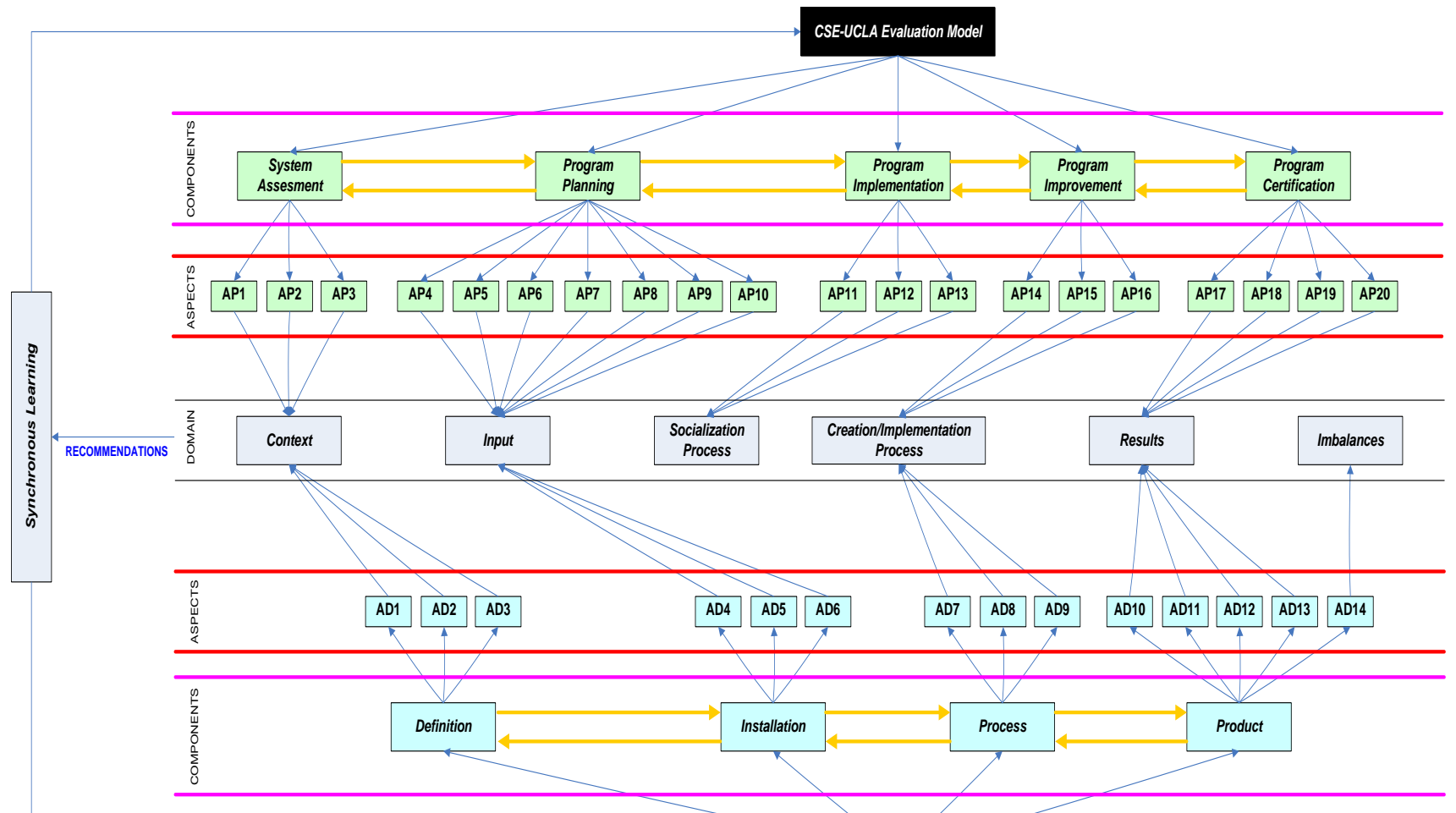

Figure 4. The Modified Design of the CSE-UCLA Model and Discrepancy Model was obtained from the Revision Results based on the Respondents' Arguments.

Figure 4 showed the revision results according to the respondents' arguments during the initial trials. Based on that figure, it can be explained thoroughly about the design formed from the modification of the CSE-UCLA model and Discrepancy model. Evidence of improvement according to the suggestions from respondent-2 and respondent-18 is indicated by a red line that shows the evaluation aspects of both the CSE-UCLA model and the Discrepancy model. The pink line is indicated the evaluation components for both the CSE-UCLA model and the Discrepancy model. Evidence of improvement according to the suggestions from respondent-10 is indicated by the presence of a black box that shows the name of the CSE-UCLA evaluation model and a brown box that shows the name of the Discrepancy model. Evidence of improvement according to the suggestions from respondent-14 is indicated by the presence of light green boxes that shows the components of the CSE-UCLA evaluation and light turquoise boxes that show the components of the Discrepancy evaluation. Evidence of improvement according to the suggestions from respondents16 is indicated by an orange arrow show one evaluation component to another that is interconnected and related. Evidence of improvement according to the suggestions from respondent-20 is indicated by one word of "RECOMMENDATIONS" in blue and using a capital letter which goes to the box "Synchronous Learning".

The percentage of effectiveness of $81.93 \%$ which was shown in Table 4 showed that the modified design of the CSE-UCLA and Discrepancy models included in the effective category. This is because that percentage is in the range of $80 \%$ to $89 \%$ which refers to the scores of effectiveness percentage. Generally, the modified results of the CSEUCLA and Discrepancy models are effectively used as an evaluation model to determine the effectiveness of the synchronous learning implementation if viewed from that effective categorization. Based on that categorization, it can also be stated that the modified model is ready for use and does not need to be revised again. However, according to the positive and constructive arguments that had been given by respondents during the initial trials, it was very good and reasonable making the revisions to improve the evaluation model design.

The key parameters needed to determine the success for realizing this modification model design are the program implementation component owned by the CSE-UCLA model and the product component owned by the Discrepancy model. The reason for used those two components as important parameters is because functionally those components complement each other. The limitation of the Discrepancy model in its inability to evaluate the socialization process domain can be complemented by the program implementation component. Likewise, the limitation of the CSE-UCLA model in its inability to evaluate the imbalances domain can be complemented by the product component.

The novelty of this research is the combination of two different evaluation models that can be used to evaluate the effectiveness of the synchronous learning implementation. The integration of evaluation components of two models can be used to measure the synchronous learning effectiveness from the context domain, input domain, socialization process domain, implementation process domain, results domain, and imbalances domain. If this research compared 
with the research was conducted by the authors previously in 2018 about the use of the CSE-UCLA model to evaluate the blended learning program at SMA Negeri 1 Ubud [26], so it has certainly a clear difference. The difference is that research conducted in 2018 had not shown specifically the evaluation component that was able to be used to measure the imbalances in the blended learning implementation.

If compared with several other studies, including Toosi et al.'s research, Lee et al.'s research, Iqbal et al.'s research, and Finney's research. Toosi et al.'s research [43] showed the use of the CIPP model to evaluate the learning quality in health universities. The limitations of Toosi et al.'s research were that it had not shown evaluation components that measure the learning quality from the socialization process domain and the imbalances domain that occurs in the learning implementation. Lee et al.'s research [44] demonstrated the use of the CIPP model to evaluate online learning in health education. The limitations of Lee et al.'s research were that it had not shown evaluation components that measure the online learning effectiveness in the viewed from socialization form of the online learning existence and the imbalances that occur in its implementation. Iqbal et al.'s research [45] showed the use of three models in evaluating the impact of educational program implementation. Limitations of Iqbal et al.'s research were that it had not shown evaluation components that measure the impact of the education programs implementation because of six domains. Those domains included: the program origin, input of resources to support the program running, the socialization process, the program implementation process, program results, and imbalances in program implementation. Finney's research [46] showed a modification of the CIPP model by adding a confirmative evaluation stage which is used to measure the effectiveness of the student learning process. The limitations of Finney's research were that it had not shown evaluation components that measure the imbalances that occur in the student learning process. Generally, from four studies, it is clear that all the results of those studies had not shown the evaluation components that measure the socialization form of the existence of a program and the imbalance that occurs in the implementation of the evaluated program.

The limitations shown from those four studies also strengthen the sensitivity of the components of the CSE-UCLA and Discrepancy models in supporting the accuracy of the evaluation results. This is because all evaluation components of the CSE-UCLA and Discrepancy models can measure the effectiveness of synchronous learning implementation accurately and completely in viewed from six domains. Those domains included: 1) context, 2) input, 3) socialization process, 4) implementation process, 5) results, and 6) imbalances in the learning implementation.

Besides, the limitations shown in those four studies can also affect the evaluation results of the learning process's effectiveness. This is because the evaluation components were used in previous studies had not been complete. Several components are not owned or not raised in the evaluation process, namely components to measure the socialization process domain and the imbalances domain. Those two evaluation components had been used in this research particularly, so certain that the evaluation results become more optimal.

Principally, this study had been able to answer the limitations of Mohmmed et al.'s research [23], Sudarwati and Rukminingsih's research [24], and Divayana et al.'s research [25] by showing the socialization process for the existence of synchronous learning and showing imbalances in the synchronous learning implementation. This research results had also shown that there was a combination of evaluation models that can be used to determine the effectiveness level of the learning implementation. This is reinforced by the results of previous research which also showed that there was a combination of several evaluation models in determining the effectiveness of a learning process implementation [47, 48]. Besides some of the advantages shown from this research, there are also several limitations. The limitations of this research are that it has not shown yet aspects are priority improvements in the synchronous learning implementation.

\section{4- Conclusion}

Generally, the design which was a modified result of the CSE-UCLA model and the Discrepancy model had good categories and was effective to be used as an innovative evaluation model design. That design can be used to determine the effectiveness level of synchronous learning. That evaluation model design was formed has a good mix of functionality. This is shown from the evaluation aspect that is not available in the CSE-UCLA model to evaluate the imbalances domain, which is represented by the evaluation aspect of the Discrepancy model. Likewise, the evaluation aspect that is not present in the Discrepancy model to evaluate the socialization process domain has been represented by the evaluation aspects of the CSE-UCLA model. The modification between CSE-UCLA and Discrepancy models is not only used as an evaluation model design to determine the effectiveness level of synchronous learning implementation. However, this modification model design can also show the measurement process of the effectiveness level of all learning programs, education services, and education policies. This modification model design can show the evaluation process of programs, services, and policies in the educational field from the dimensions of initial conditions, inputs, promotion mechanisms, processes, outputs, and imbalances. Recommendations for educational evaluators regarding the existence of an evaluation model design which is the modification results of the two evaluation models are to encourage educational evaluators to use this evaluation model design in their evaluation 
practice toward the implementation of ICT-based learning, specifically in synchronous learning. Besides, it is also recommended can use this modification model as basic to evaluate learning programs, education services, and education policies in a wider scope. Future work that is recommended to be done in overcoming the limitations of this research is to develop an innovative evaluation model based on artificial intelligence that can determine priority aspects of improvement in the synchronous learning implementation.

\section{5- Declarations}

\section{5-1-Author Contributions}

P.W.A.S. Conceptualization, methodology, data curation, formal analysis, investigation, writing-original draft, and editing; and D.G.H.D. Conceptualization, methodology, data curation, formal analysis, investigation, writing-original draft, writing-reviewing and editing. All authors have read and agreed to the published version of the manuscript.

\section{5-2-Data Availability Statement}

The data presented in this study are available in the article.

\section{5-3- Funding}

The authors received financial support based on a Research Grant with Contract Number: 461/UN48.16/LT/2021 from the Chair of the Institute for Research and Community Services, Universitas Pendidikan Ganesha for the research, authorship, and/or publication of this article.

\section{5-4-Acknowledgements}

The authors would like to express their deepest gratitude to the Chancellor and Chair of the Institute for Research and Community Services, Universitas Pendidikan Ganesha that had given the opportunity and provide the funding for the completion of this research.

\section{5-5- Conflicts of Interest}

The authors declare that there is no conflict of interests regarding the publication of this manuscript. In addition, the ethical issues, including plagiarism, informed consent, misconduct, data fabrication and/or falsification, double publication and/or submission, and redundancies have been completely observed by the authors.

\section{6- References}

[1] Coman, Claudiu, Laurențiu Gabriel Țîru, Luiza Meseșan-Schmitz, Carmen Stanciu, and Maria Cristina Bularca. "Online Teaching and Learning in Higher Education during the Coronavirus Pandemic: Students' Perspective.” Sustainability 12, no. 24, (December 11, 2020): 1-24. doi:10.3390/su122410367.

[2] Fatoni, Nurce Arifiati, Etty Nurkhayati, Ela Nurdiawati, Fidziah, Giantoro Pamungkas, Suhroji Adha, Irawan, Agus Purwanto, Octoberry Julyanto, and Enji Azizi. "University Students Online Learning System during Covid-19 Pandemic: Advantages, Constraints and Solutions." Systematic Reviews in Pharmacy 11, no. 7, (July 2020): 570-576. doi: 10.31838/srp.2020.7.81.

[3] Mardiah, Henny. "The Use of E-learning to Teach English in the Time of the Covid-19 Pandemic." English Teaching and Linguistics Journal 1, no. 2, (July 2020): 49-55. doi:10.30596/etlij.v1i2.4894.

[4] Murphy, Michael P. A. "COVID-19 and Emergency eLearning: Consequences of the Securitization of Higher Education for Post-Pandemic Pedagogy." Contemporary Security Policy 41, no. 3, (April 30, 2020): $492-505$. doi:10.1080/13523260.2020.1761749.

[5] Yulia, Henny. "Online Learning to Prevent the Spread of Pandemic Corona Virus in Indonesia." ETERNAL (English Teaching Journal) 11, no. 1, (February 2020): 48-56. doi: 10.26877/eternal.v11i1.6068.

[6] Divayana, Dewa Gede Hendra. "Utilization of DIVAYANA Formula in Evaluating of Suitable Platforms for Online Learning in the Social Distancing." International Journal of Interactive Mobile Technologies 14, no. 20, (December 20, 2020): 50-75. doi: 10.3991/ijim.v14i20.15787.

[7] Dhawan, Shivangi. “Online Learning: A Panacea in the Time of COVID-19 Crisis.” Journal of Educational Technology Systems 49, no. 1, (June 20, 2020): 5-22. doi: 10.1177/0047239520934018.

[8] Lobe, Bojana, David Morgan, and Kim A. Hoffman. "Qualitative Data Collection in an Era of Social Distancing." International Journal of Qualitative Methods 19, (July 7, 2020): 1-8. doi: 10.1177/1609406920937875.

[9] Sidpra, Jai, Celia Gaier, Nihaal Reddy, Neetu Kumar, David Mirsky, and Kshitij Mankad. (2020). Sustaining Education in the Age of Covid-19: A Survey of Synchronous Web-Based Platforms." Quantitative Imaging in Medicine and Surgery 10, no.7, (July 2020): 1422-1427. doi:10.21037/qims-20-714. 
[10] Tiur Malsari Siregar, Jamalum Purba, and Budi Ali Mukmin. "Evaluation of Implementation of Blended Learning Implementation in Universitas Negeri Medan.” Britain International of Linguistics, Arts and Education Journal 1, no. 2, (November 30, 2019): 224-231. doi:10.33258/biolae.v1i2.89.

[11] Widiharti, Wininng, Burhanuddin Tola, and Yetti Supriyati. "Evaluation of Principal Partnership Programs in the Directorate of Education Management - The Application of Kirkpartick and Countenance Stake Evaluation Model.” Universal Journal of Educational Research 7, no 9A, (September 2019): 71-77. doi:10.13189/ujer.2019.071609.

[12] Gunherani, Dewi, Wiwit Irawati, and Aeng Muhidin. "The Evaluation of E-learning Program at the University of Pamulang." Advances in Social Science, Education and Humanities Research 335, (August 2019): 710-716. doi:10.2991/icesshum19.2019.113.

[13] Embi, Zarina Che, Tse-Kian Neo, and Mai Neo. "Using Kirkpatrick's Evaluation Model in a Multimedia-Based Blended Learning Environment." Journal of Multimedia Information System 4, no. 3, (September 30, 2017 ): $115-122$. doi:10.9717/JMIS.2017.4.3.115.

[14] Youker, Brandon W., and Allyssa Ingraham. “Goal-Free Evaluation: An Orientation for Foundations' Evaluations.” The Foundation Review 5, no. 4, (February 7, 2014): 51-61. doi:10.9707/1944-5660.1182.

[15] Rosiyanti, Hastri, and Faisal. "Evaluation of E-Campus-Based E-learning Implementation by Mathematics Education Study Program Students at the University of Muhammadiyah Jakarta." Advances in Social Science, Education and Humanities Research 512, (December 31, 2020): 349-354. doi:10.2991/assehr.k.201230.065.

[16] Tripathi, J.P., and Arti Bansal. "A Literature Review on Various Models for Evaluating Training Programs.” IOSR Journal of Business and Management (IOSR-JBM) 19, no. 11, (November 2017): 14-22. doi:10.9790/487X-1911041422.

[17] Esgaiar, and Scott Foster. "Implementation of CIPP Model for Quality Evaluation at Zawia University." International Journal of Applied Linguistics \& English Literature 8, no. 5, (September 30, 2019): 106-115. doi:10.7575/aiac.ijalel.v.8n.5p.106.

[18] Mubayrik, Haifa F. Bin. "New Trends in Formative-Summative Evaluations for Adult Education.” Sage Open 10, no. 3, (July 9, 2020): 1-13. doi:10.1177/2158244020941006.

[19] Divayana, Dewa Gede Hendra, P. Wayan Arta Suyasa, and Ida Bagus Gede Surya Abadi. "Digital library Evaluation Application Based on Combination of CSE-UCLA with Weighted Product.” Journal of Engineering and Applied Sciences 14, no. 4, (February 2019): 1318-1330. doi:10.36478/jeasci.2019.1318.1330.

[20] Makaria, Eklys Cheseda. "Evaluation Study on Implementation of Home Visit Service through CSE-UCLA Model in SMP Negeri 2 Anjir Muara." Advances in Social Science, Education and Humanities Research 274, (December 2018): 68-71. doi:10.2991/iccite-18.2018.16.

[21] Ambida, Roger S., and Rizalina A. Cruz. "Extent of Compliance of a Higher Education Institution for a University System." Science Journal of Education 5, no. 3, (April 12, 2017): 90-99. doi:10.11648/j.sjedu.20170503.13.

[22] Herawati, Endang Sri Budi, Suryadi, and Bejdo Sujanto. "Evaluating the Implementation of Policy on Education Board." International Journal for Educational and Vocational Studies 1, no. 3, (July 2019): 236-243. doi:10.29103/ijevs.v1i3.1584.

[23] Mohmmed, Abdalellah O., Basim A. Khidhir, Abdul Nazeer, and Vigil J. Vijayan. "Emergency Remote Teaching during Coronavirus Pandemic: the Current Trend and Future Directive at Middle East College Oman.” Innovative Infrastructure Solutions 5, no. 72, (July 1, 2020): 1-11. doi:10.1007/s41062-020-00326-7.

[24] Sudarwati, Ninik, and Rukminingsih. "Evaluating E-learning as a Learning Media: a Case of Entrepreneurship E-learning using Schoology as Media." International Journal of Emerging Technologies in Learning 13, no. 9, (September 2018): 269279. doi:10.3991/ijet.v13i09.7783.

[25] Divayana, Dewa Gede Hendra, Baso Intang Sappaile, I Gusti Ngurah Pujawan, I Ketut Dibia, Luh Artaningsih, I Made Sundayana, and Gusti Ayu Dessy Sugiharni. “An Evaluation of Instructional Process of Expert System Course Program by using Mobile Technology-Based CSE-UCLA Model.” International Journal of Interactive Mobile Technologies 11, no. 6, (November 2017): 18-31. doi:10.3991/ijim.v11i6.6697.

[26] Suyasa, P. Wayan Arta, Putu Sukma Kurniawan, I Putu Wisna Ariawan, Wayan Sugandini, Ni Desak Made Sri Adnyawati, I Dewa Ayu Made Budhyani, and Dewa Gede Hendra Divayana. "Empowerment of CSE-UCLA Model Based on Glickman Quadrant Aided by Visual Application to Evaluate the Blended Learning Program on SMA Negeri 1 Ubud." Journal of Theoretical and Applied Information Technology 96, no. 18, (September 30, 2018): 6203-6219.

[27] Sudirtha, I Gede, Ketut Widiartini, and Made Suriani. "Program Evaluation: Implementation of Tourism Village Development." International Journal of Social Sciences and Humanities 3, no. 3, (December 2019): 99-108. doi:10.29332/ijssh.v3n3.356.

[28] Divayana, Dewa Gede Hendra, I Gede Sudirtha, and I Ketut Gading. "Application Design of Countenance Evaluation Based on Tri Hita Karana-ANEKA for Evaluating the Students' Computer Capability and Students'Character." Cogent Psychology 7, no. 1, (June 16, 2020): 1-18. doi:10.1080/23311908.2020.1773095. 
[29] Najuah, Syarifah, and Ricu Sidiq. "The Development and Utilization of E-Learning Media using the Edmodo Applications for Statistic Course.” Advances in Social Science, Education and Humanities Research (ASSEHR) 208, (May 2019): $123-126$. doi:10.2991/icssis-18.2019.24.

[30] Angelina, Patricia. "Developing Task-Based Learning Model for Language Teaching Media Course in English Language Education Study Program.” LLT Journal: A Journal on Language and Language Teaching 21, no. 1, (April 2018): 36-45. doi:10.24071/1lt.2018.210104.

[31] Etikan, Ilker, Sulaiman Abubakar Musa, and Rukayya Sunusi Alkassim. "Comparison of Convenience Sampling and Purposive Sampling." American Journal of Theoretical and Applied Statistics 5, no. 1, (January 2016): 1-4. doi:10.11648/j.ajtas.20160501.11.

[32] Shukri, Athirah, Latipah Nordin, Farah Idayu Mohd Salleh, Syazwa Nabila Mohd Raidzwan, and Rohaizan Ahmad. "UniKL Students' Perception on Synchronous Learning using ICT as Learning Tools to Learn English.” Journal of Critical Reviews 7 , no. 8, (June 2020): 793-796. doi:10.31838/jcr.07.08.170.

[33] Omillo, Francis Okumu. "Muddles in Pentatonic Likert-Type Scale: Accuracy Cost in Psychometric Measurements for Small Enterprise Development.” ILIRIA International Review 9, no. 1, (July 1, 2019): 69-83. doi:10.21113/iir.v9i1.476.

[34] Louangrath, P. I., and Chanoknath Sutanapong. "Validity and Reliability of Survey Scales." International Journal of Research \& Methodology in Social Science 4, no. 3, (December 31, 2018): 99-114. doi:10.5281/zenodo.2545038.

[35] Pescaroli, Gianluca, Omar Velazquez, Irasema Alcántara-Ayala, Carmine Galasso, Patty Kostkova, and David Alexander. "A Likert Scale-Based Model for Benchmarking Operational Capacity, Organizational Resilience, and Disaster Risk Reduction.” International Journal of Disaster Risk Science 11, (May 19, 2020): 404-409. doi:10.1007/s13753-020-00276-9.

[36] Ismanto. "Aspect of Language on a Qualitative Analysis of Student's Evaluation Instrument." Qudus International Journal of Islamic Studies 4, no. 2, (August 2016): 218-232. doi:10.21043/qijis.v4i2.1788.

[37] Ruslan, Alimuddin, and Nasrullah. "Developing Alternative Assessment of Mathematical Performance for Vocational Students." Innovation of Vocational Technology Education 14, no. 1, (February, 2018): 32-37. doi:10.17509/invotec.v14i1.11045.

[38] Wiyasa, Putu Irmayanti, I Ketut Darma Laksana, and Ni Luh Ketut Mas Indrawati. "Evaluating Quality of Teacher-Developed English Test in Vocational High School: Content Validity and Item Analysis.” Education Quarterly Reviews 2, no. 2, (May 24, 2019): 344-356. doi:10.31014/aior.1993.02.02.67.

[39] Boyac1, Ş. Dilek Belet, and Nurhan Atalay. "A Scale Development for $21^{\text {st }}$ Century Skills of Primary School Students: A Validity and Reliability Study." International Journal of Instruction 9, no. 1, (January 2016): $133-148$. doi:10.12973/iji.2016.9111a.

[40] Cárdenas-Gutiérrez, Antonio Ramón, Antonio Bernal-Guerrero, and Elisabet Montoro-Fernández. "Construction and Validation of the Basic Scale of Entrepreneurial Competencies for the Secondary Education Level. A Study Conducted in Spain.” Plos One 16, no. 4, (April 15, 2021): 1-21. doi:10.1371/journal.pone.0249903.

[41] Ginting, Fiber Yun. “An Analysis of Students' Ability in using Punctuation Marks in Descriptive Paragraph Writing”, Budapest International Research and Critics Institute-Journal 1, no. 3, (October 2018): 338-344. doi:10.33258/birci.v1i3.57.

[42] Sugiharni, Gusti Ayu Dessy. "The Development of Interactive Instructional Media Oriented to Creative Problem Solving Model on Function Graphic Subject.” Journal of Educational Research and Evaluation 2, no. 4, (November 2018): 183-189. doi:10.23887/jere.v2i4.16694.

[43] Toosi, Monireh, Maryam Modarres, Mitra Amini, and Mehrnaz Geranmayeh. "Context, Input, Process, and Product Evaluation Model in Medical Education: A Systematic Review." Journal of Education and Health Promotion 10, no. 1, (May 31, 2021): 199. doi:10.4103/jehp.jehp_1115_20.

[44] Lee, So Young, Jwa-Seop Shin, and Seung-Hee Lee. "How to Execute Context, Input, Process, and Product Evaluation Model in Medical Health Education.” Journal of Educational Evaluation for Health Professions 16, no. 40 (December 28, 2019 ): 1-8. doi:10.3352/jeehp.2019.16.40.

[45] Iqbal, Zafar, Muhammad Anees, Rahim Khan, Abdul Wadood, and Shakila Malik. "A Comparative Analysis of the Efficacy of Three Program-Evaluation Models -A Review on their Implication in Educational Programs." Humanities \& Social Sciences Reviews 9, no. 3, (May 12, 2021): 326-336. doi:10.18510/hssr.2021.9333.

[46] Finney, Tia L. “Confirmative Evaluation: New CIPP Evaluation Model.” Journal of Modern Applied Statistical Methods 18, no. 2, (November 2019): 2-24. doi:10.22237/jmasm/1598889893.

[47] Gandomkar, Roghayeh. "Comparing Kirkpatrick's Original and New Model with CIPP Evaluation Model." Journal of Advances in Medical Education \& Professionalism 6, no. 2, (March 2018): 94-95. doi:10.30476/jamp.2018.41014.

[48] Winaryati, Eny, Mardiana, and Muhamad Taufik Hidayat. “Conceptual Framework of Evaluation Model on 4C'S-Based Learning Supervision.” International Journal of Learning, Teaching and Educational Research 19, no. 8, (August 2020): 173193. doi:10.26803/ijlter.19.8.10. 